\title{
Reactive Infiltration Processing and Secondary Compressive Creep of NiAl and NiAl-W Composites
}

\author{
T.A. VENKATESH and D.C. DUNAND
}

Reactive infiltration processing was used to fabricate bulk NiAl and fiber-reinforced NiAl composites. Homogenous, pore-free materials were obtained by chemical reaction between nickel and aluminum after complete infiltration with liquid aluminum of preforms of nickel wires (containing tungsten wires for the composites) with low surface-to-volume ratio, high permeability, and regular infiltration paths. Reactively-processed, monolithic NiAl exhibited compressive creep properties at $715{ }^{\circ} \mathrm{C}$ and $1025{ }^{\circ} \mathrm{C}$ in good agreement with those of conventionally processed NiAl. The compressive creep behavior of NiAl composites reinforced with 5 to 20 vol pct W was also characterized at the same temperatures. At $715^{\circ} \mathrm{C}$, the NiAl-W composites exhibited secondary creep with little primary and tertiary creep, while at $1025^{\circ} \mathrm{C}$, the composites displayed all three stages. Microstructurally, secondary creep was characterized by pure uniaxial compression of tungsten fibers. The measured composite secondary creep rates could be predicted reasonably well with the role-of-mixtures isostrain model developed for composites where both phases undergo creep deformation using tensile creep data measured on the as-received tungsten fibers.

\section{INTRODUCTION}

THE intermetallic NiAl, with its low density, high melting point, good oxidation resistance, high thermal conductivity, and a wide range of compositional stability, is a potential candidate for replacement of nickel-based superalloys and for the matrix material of composites in high-temperature structural applications. ${ }^{[1,2,3]}$ The two main limitations of NiAl as a structural material are its poor creep strength at high temperatures and its low ductility and toughness below the brittle-to-ductile transition temperature. Several methods (e.g., alloying, directional solidification to obtain single crystals, and addition of ceramic or refractory metallic reinforcements) have been developed to address the first problem, ${ }^{[2,4]}$ while ductile phase toughening, crack bridging, or crack deflection mechanisms have demonstrated potential in enhancing the fracture toughness of $\mathrm{NiAl} .^{[5,6,7]}$

Because of their high melting points and reactivity, $\mathrm{NiAl}$ and $\mathrm{NiAl}$ composites are difficult to process by conventional casting, pressure infiltration, ${ }^{[8]}$ or powder metallurgy techniques. ${ }^{[9]}$ Reactive processing, where nickel and aluminum react exothermally to synthesize nickel aluminide, has the potential to simplify these processing problems ${ }^{[10]}$ Reactive infiltration is a recently developed method where liquid aluminum infiltrates and reacts with a solid nickel preform. ${ }^{[11-15]}$ It is also well suited for the fabrication of NiAl composites with continuousfibers such as alumina, tungsten, and molybdenum, which exhibit excellent thermodynamic stability with $\mathrm{NiAl}$ at typical processing and component service temperatures. ${ }^{[16]}$

However, it has been demonstrated that inhomogeneous microstructures are often obtained with reactive infiltration

T.A. VENKATESH, Postdoctoral Research Associate, is with the Department of Materials Science and Engineering, Massachusetts Institute of Technology, Cambridge, MA 02139. D.C. DUNAND, Associate Professor, formerly with the Department of Materials Science and Engineering, Massachusetts Institute of Technology, is with the Department of Materials Science and Engineering, Northwestern University, Evanston, IL 60208.

Manuscript submitted February 24, 1999. of nickel-powder preforms because their high surface-tovolume ratio, low permeability, and irregular infiltration paths lead to simultaneous infiltration and reaction. ${ }^{[17,18]}$ As nickel-wire preforms exhibit a lower surface-to-volume ratio, higher permeability, and more regular infiltration paths, it is expected that infiltration could be completed before the onset of reaction, resulting in more homogeneous microstructures.

The present article reports on the structure and creep properties of unreinforced and fiber-reinforced NiAl fabricated by reactive infiltration. First, the microstructural features of the matrix (porosity, stoichiometry, and grain size) and fibers (recrystallization and reactivity with the matrix) are discussed based on the processing history. Second, the observed compressive creep behavior of the composites are compared to a simple isostrain composite model, using the independently measured creep properties of matrix and fibers.

\section{EXPERIMENTAL PROCEDURES}

\section{A. Reactive Infiltration Processing}

For monolithic NiAl, nickel wires (380- $\mu$ m diameter, 99.8 pct purity, Johnson Matthey, Wardhill, MA) were bundled into preforms (40 to $50 \mathrm{~mm}$ in length and $25 \mathrm{~mm}$ in diameter) with about 38 pct average volume fraction nickel, close to equiatomic $\mathrm{NiAl}$ stoichiometry. These preforms were introduced into a flat-bottomed quartz crucible coated with a zirconia slurry. This coating served as a reaction barrier and virtually eliminated silicon contamination from the quartz crucible of liquid aluminum prior to the reaction and of liquid NiAl after the reaction. The preform was placed at one of two locations. In the first configuration, the preform was positioned above the aluminum billet (Figure 1a), where frictional forces prevented it from sliding down and contacting aluminum. The top of the crucible was insulated with fibrous alumina to minimize heat losses, wrapped with 
Table I. Experimental Parameters for the Compressive Creep Investigation of NiAl-W Composites

\begin{tabular}{|c|c|c|c|c|c|}
\hline Experiment & Temperature $\left({ }^{\circ} \mathrm{C}\right)$ & Stress $(\mathrm{MPa})$ & $\begin{array}{c}\text { Aspect Ratio/ } \\
\text { Cross Section/Platen }\end{array}$ & $\dot{\varepsilon}_{\min }\left(\mathrm{s}^{-1}\right)$ & $\begin{array}{c}\text { Tungsten Volume } \\
\text { Fraction (Pct) }\end{array}$ \\
\hline 1 & 1025 & 80 & $2 / \mathrm{C} / \mathrm{R}$ & $1.6 \cdot 10^{-6}$ & 6.3 \\
\hline 2 & $"$ & $"$ & $2 / \mathrm{C} / \mathrm{F}$ & $1.3 \cdot 10^{-6}$ & 7.0 \\
\hline 3 & $"$ & $"$ & 4/S/R & $1.5 \cdot 10^{-7}$ & 8.2 \\
\hline 4 & $"$ & $"$ & $2 / \mathrm{C} / \mathrm{F}$ & $4.9 \cdot 10^{-7}$ & 8.3 \\
\hline 5 & $"$ & $"$ & $2 / \mathrm{C} / \mathrm{F}$ & $2.0 \cdot 10^{-7}$ & 9.2 \\
\hline 6 & $"$ & $"$ & $2 / \mathrm{S} / \mathrm{F}$ & $4.6 \cdot 10^{-7}$ & 9.5 \\
\hline 7 & $"$ & $"$ & $2 / \mathrm{S} / \mathrm{F}$ & $3.0 \cdot 10^{-7}$ & 9.6 \\
\hline 8 & $"$ & 120 & $2 / \mathrm{S} / \mathrm{F}$ & $2.1 \cdot 10^{-5}$ & 10.5 \\
\hline 9 & $"$ & $"$ & $4 / S / R$ & $8.0 \cdot 10^{-7}$ & 11.5 \\
\hline 10 & $"$ & $"$ & $2 / \mathrm{S} / \mathrm{R}$ & $9.6 \cdot 10^{-7}$ & 11.8 \\
\hline 11 & $"$ & $"$ & 2/S/R & $1.8 \cdot 10^{-5}$ & 11.8 \\
\hline 12 & $"$ & $"$ & 2/S/R & $3.5 \cdot 10^{-7}$ & 12.6 \\
\hline 13 & $"$ & $"$ & $2 / \mathrm{S} / \mathrm{R}$ & $7.6 \cdot 10^{-7}$ & 14.3 \\
\hline 14 & $"$ & $"$ & $4 / \mathrm{S} / \mathrm{R}$ & $6.4 \cdot 10^{-7}$ & 14.9 \\
\hline 15 & $"$ & $"$ & 4/S/R & $3.5 \cdot 10^{-7}$ & 15.5 \\
\hline 16 & 715 & 102 & $2 / \mathrm{C} / \mathrm{F}$ & $4.4 \cdot 10^{-9}$ & 6.6 \\
\hline 17 & $"$ & 205 & $2 / \mathrm{C} / \mathrm{F}$ & $1.0 \cdot 10^{-7}$ & 6.6 \\
\hline 18 & $"$ & 200 & $2 / \mathrm{S} / \mathrm{F}$ & $1.1 \cdot 10^{-8}$ & 10.6 \\
\hline 19 & $"$ & 300 & $2 / \mathrm{C} / \mathrm{F}$ & $6.8 \cdot 10^{-6}$ & 5.8 \\
\hline 20 & $"$ & $"$ & $2 / \mathrm{C} / \mathrm{F}$ & $4.1 \cdot 10^{-6}$ & 9.9 \\
\hline 21 & $"$ & $"$ & $2 / \mathrm{S} / \mathrm{F}$ & $8.2 \cdot 10^{-7}$ & 10.6 \\
\hline
\end{tabular}

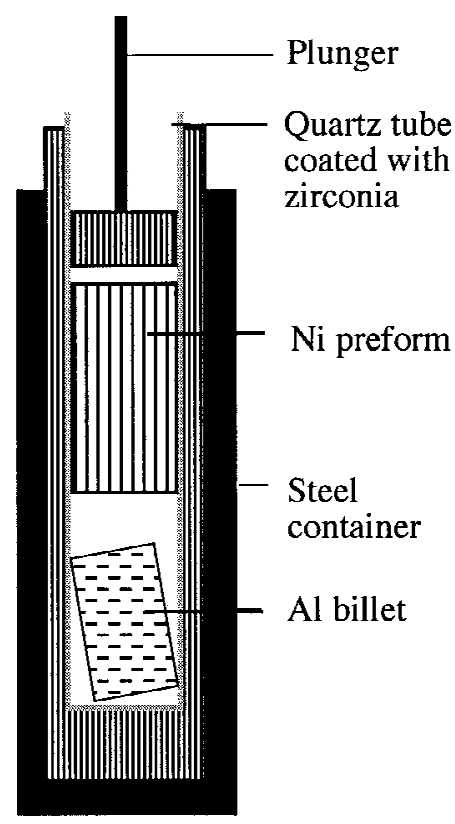

(a)

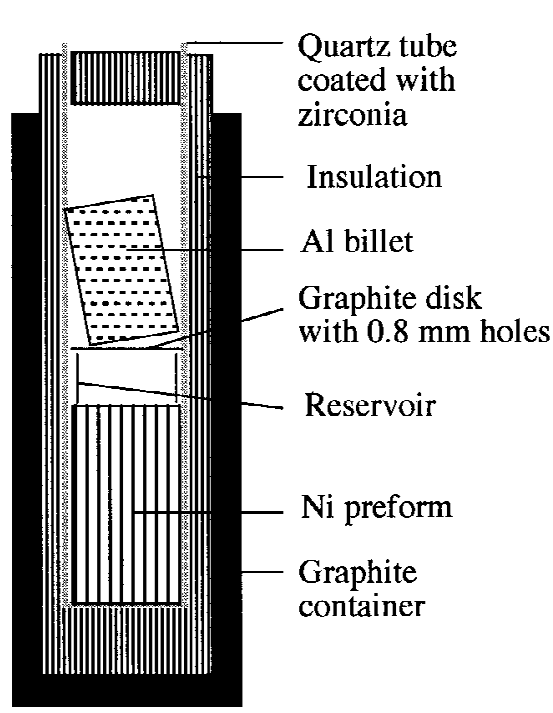

(b)

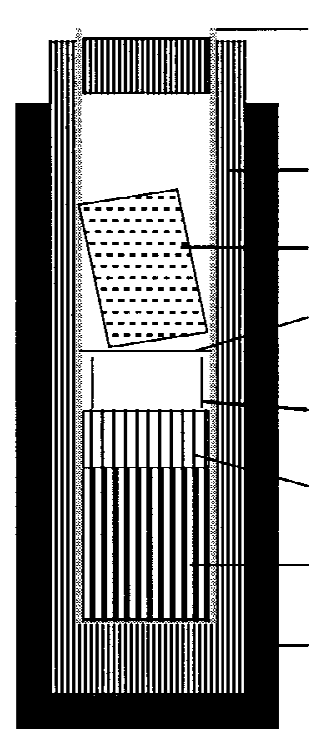

Quartz tube coated with zirconia

Insulation

Al billet

Graphite disk with $0.8 \mathrm{~mm}$ holes

Reservoir

Ni preform

Composite preform Graphite container

Fig. 1-Schematics illustrating processing of (1) NiAl from nickel-wire preforms using (a) a plunger and (b) gas pressure mechanisms; and (2) NiAlcomposites $(c)$ with tungsten.

insulating ceramic wool, and placed in another steel or graphite crucible. The assembly was lowered into a pressure infiltration rig described in Reference 19 and heated to $710{ }^{\circ} \mathrm{C}$ under vacuum. A plunger mechanism then slowly slid the nickel-wire preform into the pool of liquid aluminum, leading to the formation of nickel aluminide. The setup was then allowed to cool under vacuum. In the second configuration (described in more detail in References 15 and 20), the nickel preform was placed at the bottom of the crucible
(Figure 1(b)). A gating system comprised of a graphite ring with a graphite disk on top (1 to $2 \mathrm{~mm}$ in thickness and with 40 to 50 uniformly spaced, hand-drilled 0.8 -mm holes) was placed on top of the wire preform. The gating system enabled liquid aluminum, which was forced upon gas pressurization through the graphite disk, to first collect in the reservoir space beneath the disk before infiltrating the preform with a planar front. The crucibles were insulated and introduced into the pressure infiltration apparatus as 
described previously. The setup was heated under vacuum to $710{ }^{\circ} \mathrm{C}$, and the chamber was pressurized with argon $(2.8$ $\mathrm{MPa}$ ) forcing liquid aluminum to infiltrate the preform and react with nickel to form nickel aluminide. The pressure was maintained for a few minutes before depressurization of the apparatus that was cooled with its residual argon atmosphere.

For NiAl composites, continuous fiber preforms were fabricated by adding 9 vol pct tungsten fibers $(250-\mu \mathrm{m}$ diameter, 50-mm length, 99.8 pct purity, Johnson Matthey) in the nickel-wire preforms (Figure 1(c)). Care was taken to maximize distribution homogeneity and minimize distortion of the reinforcing fibers. Because NiAl is denser than the corresponding equiatomic mixture of metallic nickel and aluminum, the NiAl melt formed in the crucible had a height lower than that of the infiltrated, unreacted perform. Hence, reinforcing fibers of the same height as the preform emerged from the reacted melt and clustered because of capillary effects, leading to an inhomogeneous distribution and misalignment of fibers in the composite. To eliminate this problem, a short layer of fiber-free nickel-wire preform was placed on top of the composite preform. After infiltration and reaction, this molten top layer served as a feed compensating for the reaction volume shrinkage.

Optical metallography, backscattered scanning electron microscopy (SEM), and electron-microprobe analysis were performed to characterize the microstructural features such as grain size, porosity, homogeneity, and the nature of the reinforcement matrix interface. All samples were prepared by polishing with $\mathrm{SiC}$ paper and $1-\mu \mathrm{m}$ diamond paste. Optical metallographic samples were subsequently etched with Kalling's reagent $\left(5 \mathrm{~g}\right.$ of $\mathrm{CuCl}_{2}$ in $100 \mathrm{~mL}$ of $\mathrm{HCl}$ ) for 30 to 60 seconds for $\mathrm{NiAl}$ and $\mathrm{NiAl}$ composites and a solution of $\mathrm{NaOH}+\mathrm{K}_{3} \mathrm{Fe}(\mathrm{CN})_{6}$ for 30 seconds for tungsten fibers.

\section{B. Creep Testing}

Creep samples were electrodischarge machined from the midsections of the as-cast ingots produced by the infiltration method (Figure 1(b)) and were 10 or $20 \mathrm{~mm}$ in height and with circular or square cross sections, $5 \mathrm{~mm}$ in diameter or width, respectively. The composite samples had fibers aligned in the longitudinaldirection. Constant-load compression creep tests were performed in air. A superalloy creep cage translated tensile loads in the pull rods to compressive stresses on the sample. Frictional effects on the end-loaded samples were reduced by using boron nitride coated flat alumina platens in the creep cage. Alumina platens with a recess depth of $1 \mathrm{~mm}$ were also used in some experiments to prevent sample brooming. Sample temperature was measured using a type $\mathrm{K}$ thermocouple in contact with the sample and was maintained within $1{ }^{\circ} \mathrm{C}$ of the set temperature through the duration of the experiment. Sample strains were calculated from extensometric displacements of the platens measured with a linear variable differential transducer accurate to $1 \mu \mathrm{m}$.

Compression creep tests were performed on unreinforced $\mathrm{NiAl}$ and NiAl-W composites (Table I) at $715^{\circ} \mathrm{C}$ and 1025 ${ }^{\circ} \mathrm{C}$, within an applied stress range of 15 to $300 \mathrm{MPa}$. The samples were heated to the test temperature in approximately 1 hour, subsequently soaked at the test temperature for 1 hour, and then loaded in approximately 10 seconds. Tension creep tests were performed on tungsten wires (obtained from the same stock as used for composites) in vacuum at 715 ${ }^{\circ} \mathrm{C}$ and $1025^{\circ} \mathrm{C}$ within an applied stress range of 450 to $1260 \mathrm{MPa}$. The ends of the tungsten wires were wound about 10 times on threaded molybdenum pins and held by friction, resulting in a $100-\mathrm{mm}$ gage section. The pins were inserted in standard superalloy pull heads connected to superalloy pull rods through which a tensile load was applied. The vacuum was maintained at 0.1 mtorr through the duration of the experiment. The temperature was measured by a K-type thermocouple placed close to the tungsten wire in the vacuum chamber and was maintained within 1 ${ }^{\circ} \mathrm{C}$ of the test temperature. The samples were typically brought to the test temperature in 1 hour, soaked at the test temperature for 30 minutes, and loaded by adding appropriate dead weights. Creep strains were determined from load-train displacement measurements.

The matrix of as-cast and creep-tested NiAl-W composites was dissolved in aqua-regia ( $3 \mathrm{HCl}: 1 \mathrm{HNO}_{3}$ by volume) at room temperature for times between 4 and 8 hours to extract the tungsten fibers. As-received tungsten fibers were also treated with aqua-regia and were found to be essentially insoluble. From a count of the number of tungsten fibers recovered from each tested composite sample, the volume fraction of tungsten in the composite samples was obtained. If the recovered fibers had lengths shorter than the length of the creep sample, their contribution to the overall volume fraction was weighted down in proportion to their lengths. Even though the composite ingots had a nominal tungsten volume fraction of 9 pct (equivalent to about 9 at pct tungsten based on the amounts of reactants, nickel and aluminum, present in the preform prior to their reaction to form nickel aluminide), the creep samples had volume fractions in the range 5 to 20 pct due to fiber distribution inhomogeneity.

\section{RESULTS}

\section{A. Reactive Infiltration Processing}

For monolithic NiAl, reactive infiltration of the wire preforms using the gas-pressure technique (Figure 1(b)) resulted in ingots with a macrostructure characterized by a predominantly single-phase, pore-free $\mathrm{NiAl}$ region with a dendritic and coarse-grained structure in some cases (Figure 2(b)) or a coarse-grained structure with a grain size of approximately $200 \mu \mathrm{m}$ (Figure 2(d)) in most cases. A porous aluminumrich region formed at the ingot top (Figure 2(a)). Electron probe microanalysis indicated that within the NiAl region, the elemental compositions varied linearly from about 53 at. pet Ni toward the ingot top to about 64 at. pet Ni toward the ingot bottom (Figure 2(c)). The ingots obtained using the plunger technique (Figure 1(a)) exhibited, in some cases, a uniform microstructure but in most cases showed a graded microstructure, similar to that obtained using the gas-pressure technique. Creep test samples were fabricated from the mid-section of coarse-grained ingots (where the composition was near stoichiometric) processed using the gas-pressure technique.

For NiAl-W composites, the wire preforms with aligned continuous tungsten fibers were completely infiltrated and fully reacted to form a pore-free NiAl matrix (with a grain size of approximately $200 \mu \mathrm{m}$ ) in the bulk of the ingot and with a porous aluminum-rich layer at the top of the ingot. The tungsten fibers were quite well aligned. Although some 

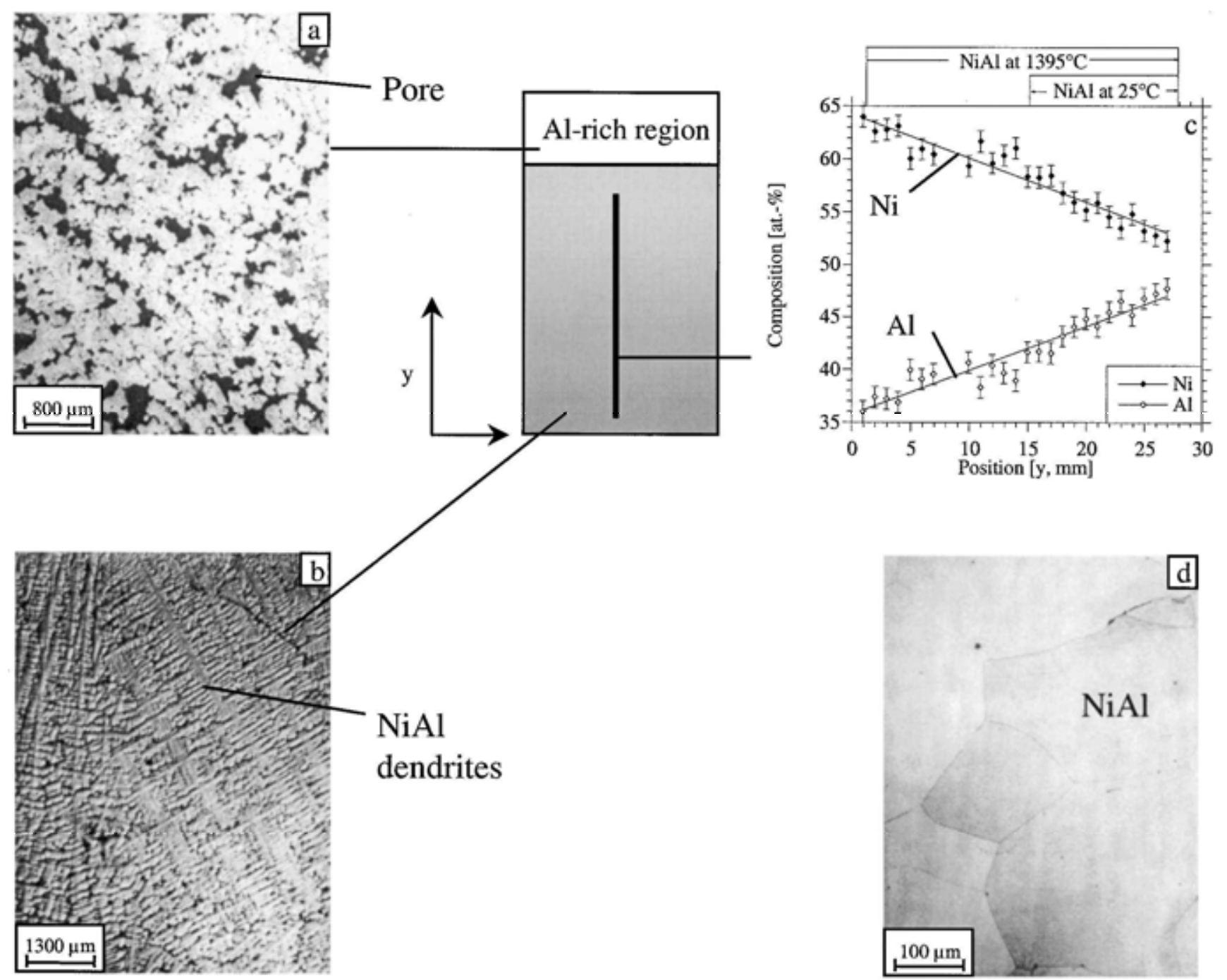

Fig. 2-NiAl ingot macrostructure with (a) an Al-rich porous top region, $(b)$ a dendritic and coarse-grained or $(d)$ a coarse-grained bottom region, and (c) a composition profile in the middle region. Microstructures (a) and (b) were obtained from an ingot with an average composition of 49 at. pct $\mathrm{Ni}$ (based on amounts of reactants, nickel and aluminum, present prior to reaction to form nickel aluminide).

tungsten dissolution and NiAl-W eutectic formation were observed (Figure 3), the fiber/matrix interface was sharp and chemically unreacted. The peripheral region of the tungsten fibers was recrystallized to a depth of about $15 \mu \mathrm{m}$ (corresponding to about 22 vol pct of each tungsten fiber), leading to a microstructure consisting of equiaxed grains with a size of about $10 \mu \mathrm{m}$ (Figure 4). The core of the tungsten wires retained their as-drawn texture and exhibited narrow, elongated grains (approximately $100-\mu \mathrm{m}$ long and $2-\mu \mathrm{m}$ wide). As seen in Figure 4 the top and the bottom edges of the tungsten fibers showed extensive recrystallization. The strain induced at the tips of the fibers upon sectioning to the desired lengths while the preform bundles were prepared may have contributed to the enhanced recrystallization at the fiber edges.

\section{B. Creep Properties}

Unreinforced NiAl specimens, creep tested in compression at $715{ }^{\circ} \mathrm{C}$ and $1025{ }^{\circ} \mathrm{C}$, reached a secondary stage after a very short primary stage. As shown in Figure 6, the minimum strain rate $\dot{\varepsilon}$ can be described by a power law

$$
\dot{\varepsilon}=A \exp \left[-\frac{Q}{\mathrm{R} T}\right] \sigma^{n}
$$

where $\sigma$ is the stress, $A$ is a constant for a given temperature that takes into account microstructural variables, $Q$ is the activation energy for creep, and $\mathrm{R}$ is the universal gas constant. The experimentally determined stress exponents $n$ and constants $K=A * \exp (-Q / \mathrm{R} T)$ are tabulated in Table II. An activation energy of $375 \mathrm{~kJ} / \mathrm{mol}$ was obtained for the creep deformation of $\mathrm{NiAl}$ using Eq. [1] (at 50 and $100 \mathrm{MPa}$ ) for the two temperatures, $715^{\circ} \mathrm{C}$ and $1025^{\circ} \mathrm{C}$, investigated.

Tungsten wires creep tested in tension at $715^{\circ} \mathrm{C}$ (Figure 7) and $1025^{\circ} \mathrm{C}$ (Figure 8) reached a minimum strain rate after a fairly pronounced primary stage, especially at 1025 ${ }^{\circ} \mathrm{C}$. As shown in Figure 9, the minimum strain rate, $\dot{\varepsilon}_{\text {min }}$, can be described by a power law (Eq. [1]) with the experimentally determined creep constants listed in Table II. The total creep strain accumulated in the primary stage, at 1025 ${ }^{\circ} \mathrm{C}$ (Figure 10), can be modeled according to Andrade's law

$$
\varepsilon_{f}=\dot{\varepsilon}_{\min } t+q t^{1 / 3}
$$




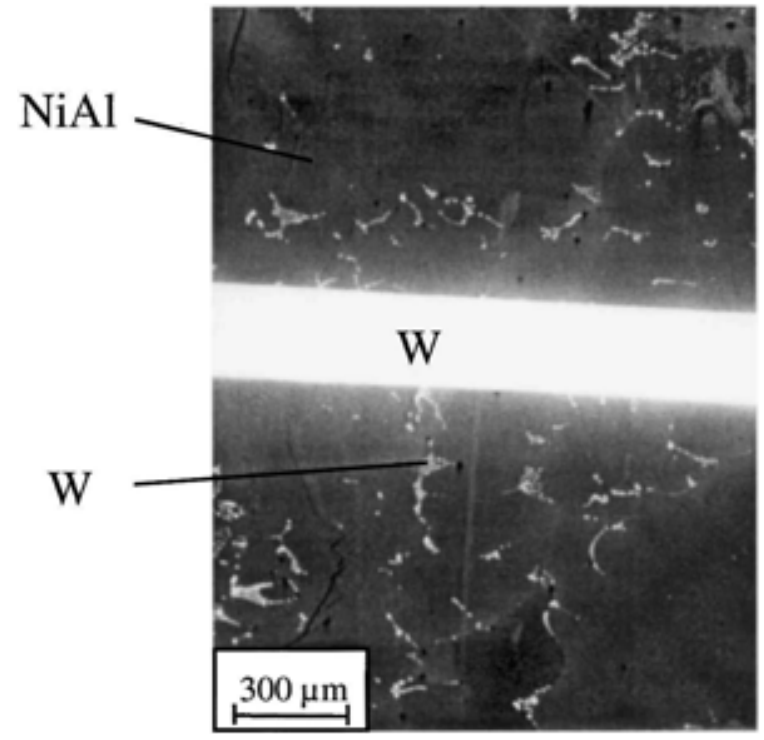

Fig. 3-SEM microstructure of a NiAl composite with 9 vol. pct tungsten obtained from an ingot with an average composition of 45 at. pct Ni, 46 at. pct $\mathrm{Al}$, and 9 at. pct $\mathrm{W}$ (calculated based on the amounts of reactants, nickel and aluminum, present prior to reaction to form nickel aluminide).

where $\dot{\varepsilon}_{\text {min }}$ is the minimum creep rate, and $q$ is a constant that varies with the applied stress.

The NiAl-W composites displayed two types of behavior. First, at $715^{\circ} \mathrm{C}$, all experiments exhibited stable minimum strain rates over large strains on the order of 10 pct (Figure 11). Neither primary nor tertiary creep was observed. Second, at $1025^{\circ} \mathrm{C}$, all experiments, irrespective of platen type or sample aspect ratios, exhibited visible primary creep and stable minimum strain rates over varying amounts of strains, followed by a tertiary stage with a rapid increase in the strain rates (Figure 12).

When compared to the volume fraction of tungsten present in the samples prior to creep testing obtained by density measurements, there was a clear indication of loss of tungsten, from the free surface of the samples, upon long-term exposure to air at $715^{\circ} \mathrm{C}$ and $1025^{\circ} \mathrm{C}$. A visual inspection of the creep-tested samples confirmed oxidation of tungsten fibers intersecting the lateral sides of the specimen, with a yellow-green oxide of tungsten found curling out of the sample lateral sides. Most of the fibers did not intersect the specimen sides and were protected from oxidation by the $\mathrm{NiAl}$ matrix. It was also determined from trial experiments that almost all of the oxidation occurred during the heating and soaking stage prior to the application of loads to the samples. Thus, it was inferred that there was no change in the tungsten volume fraction during the actual creep tests. Because the tungsten volume fractions reported in Table I were always determined after creep testing, they are representative of those present during deformation.

\section{DISCUSSION}

\section{A. Processing}

The reactive infiltration process comprises two steps, physical infiltration and chemical reaction. Dominance of either of these steps leads to two limits: ${ }^{[15,17]}$ (1) rapid reaction rate with low infiltration rate and (2) rapid infiltration
Table II. The $715{ }^{\circ} \mathrm{C}$ and $1025^{\circ} \mathrm{C}$ Power-Law Creep Constants Determined from Compression and Tension Creep of NiAl and W, Respectively

\begin{tabular}{cccccc}
\hline \multirow{2}{*}{$\begin{array}{c}\text { Temperature } \\
\left({ }^{\circ} \mathrm{C}\right)\end{array}$} & \multicolumn{3}{c}{$\mathrm{NiAl}$} & & $\mathrm{W}$ \\
\cline { 2 - 3 } \cline { 5 - 6 } & $n$ & $K\left(\mathrm{MPa}^{-n} \mathrm{~s}^{-1}\right)$ & & $n$ & $K\left(\mathrm{MPa}^{-n} \mathrm{~s}^{-1}\right)$ \\
\hline 715 & 5.5 & $1.7410^{-18}$ & & 13.6 & $3.8310^{-49}$ \\
1025 & 5.6 & $6.3710^{-14}$ & & 6.8 & $3.4810^{-26}$ \\
\hline
\end{tabular}

rate with low reaction rate. Powder preforms, used, e.g., in References 11 through 13, with high surface-to-volume ratios, low permeability, and irregular infiltration paths, conform to the first limit. As different regions of the sample react at different times and to different extents, the resulting macrostructures are often characterized by an irregular distribution of multiphase intermetallics. On the other hand, wire preforms used in the present study and in Reference 15 have lower surface-to-volume ratio, higher permeability, and regular infiltration paths and, thus, conform to the second limit. In this case, reactive infiltration can be envisioned as two processes, infiltration and reaction, occurring sequentially and separated by an incubation period. For an equiatomic Ni-Al mixture reacting at $700{ }^{\circ} \mathrm{C}$ under adiabatic conditions, thermodynamic calculations ${ }^{[14]}$ predict that all of the product $\mathrm{NiAl}$ formed will be in the liquid state. The dendritic structure of NiAl (Figure 2(b)) confirms that the intermetallic was molten and, thus, validates the assumption that $\mathrm{NiAl}$ synthesis is near adiabatic. A type-K thermocouple placed in the preform prior to preform infiltration recorded a sharp spike in the temperature upon infiltration of the preform with liquid aluminum, indicating the ignition of reaction between nickel and aluminum. SanMarchi and Mortensen ${ }^{[15]}$ also reported formation of molten NiAl for preforms with 0.38 - and 1-mm diameter nickel wires and similar ignition temperatures as studied here. As demonstrated in References 17 and 18, the kinetics of the reaction between nickel and aluminum is expected to be a strong function of the surface-area-to-volume ratio of nickel. References 15 and 20 demonstrated that when nickel wire preform concentrations fall within the range of 40 to 53 at. pct, an aluminumrich layer occurs on top of the $\mathrm{NiAl}$ layer for all preforms, independent of the preform volume fractions. This effect was attributed in part to rapid movement of unreacted aluminum pools to the top of the molten intermetallic driven by buoyancy forces. The present results for wire preform experiments with nickel compositions around 50 at. pct (i.e., preform volume fractions around $38 \mathrm{vol}$ pct) confirm the previous observation. In experiments using the gas-pressure technique, the NiAl samples exhibited a linear composition gradient with concentrations typically ranging from about 53 at. pet Ni toward ingot top to about 64 at. pct Ni toward ingot bottom. This macrosegregation can be explained as follows. ${ }^{[1,15]}$ At equilibrium, the nickel solubility in liquid aluminum is 5 at. pct at $710{ }^{\circ} \mathrm{C},{ }^{[21]}$ so that nickel fibers are expected to dissolve in pure aluminum. Thus, nickel fiber erosion through dissolution at the top of the preform by pure aluminum flowing from the liquid pool is more pronounced than at the bottom of the preform, because (1) the total amount of liquid passing through the preform decreases from top to bottom, and (2) the nickel concentration of the flowing aluminum melt increases from top to bottom. Thus, at the end of infiltration but before reaction, a concentration gradient in 

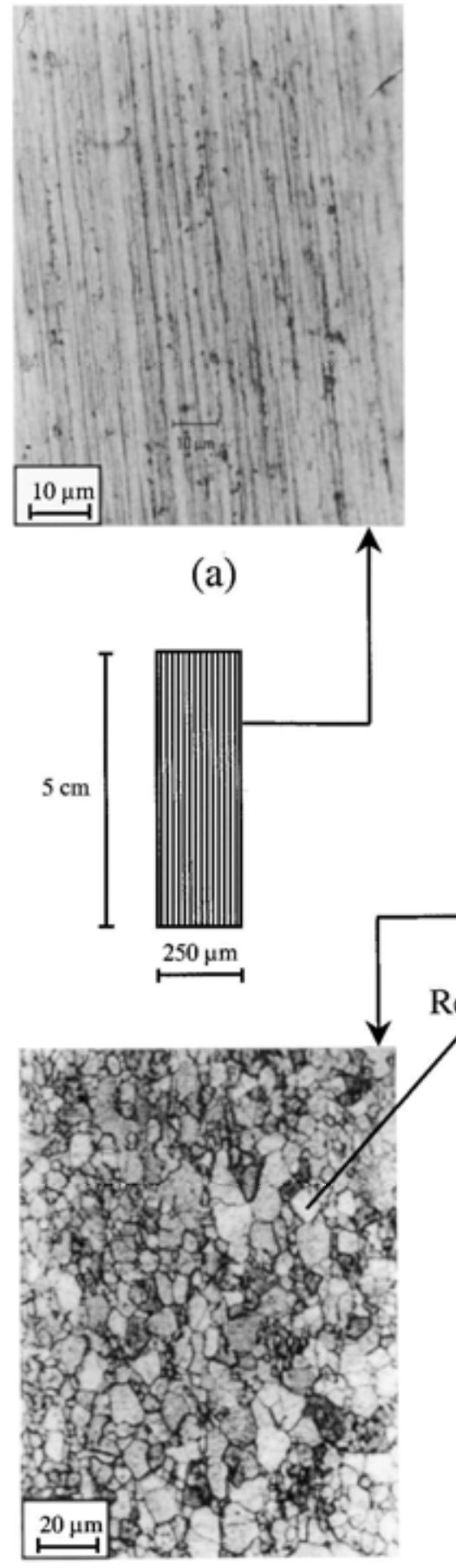

(c)

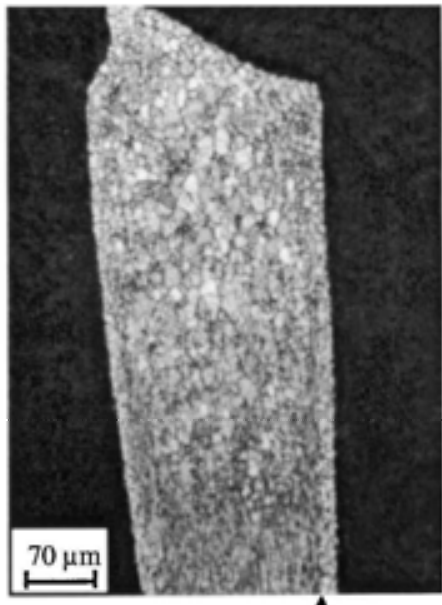

(b) 
$\mathrm{Ni}$ and 59 at. pct Ni. ${ }^{[21]}$ Hence, if complete thermodynamic equilibrium is obtained in the reactive infiltration process, the ingot midsection is expected to be single-phase $\mathrm{NiAl}$ (Figure 2(c)), while the ingot bottom is expected to be a two-phase mixture of $\mathrm{NiAl}$ and $\mathrm{Ni}_{5} \mathrm{Al}_{3}$. At higher temperatures, the width of the single-phase $\mathrm{NiAl}$ domain is larger (reaching at $1395{ }^{\circ} \mathrm{C}$ a maximum of 42 to 68 at. pct $\mathrm{Ni}^{[21]}$ ) so that a melt with 64 at. pct $\mathrm{Ni}$ is expected to solidify as single-phase NiAl. A review of literature, ${ }^{[22-28]}$ summarized in Table III, indicates that nickel-rich NiAl with compositions ranging from 62.5 to 66.2 at. pct $\mathrm{Ni}$, upon homogenization in the single-phase $\beta$ region at temperatures between $1000{ }^{\circ} \mathrm{C}$ and $1300{ }^{\circ} \mathrm{C}$, and subsequent rapid cooling does not transform to the $\mathrm{Ni}_{5} \mathrm{Al}_{3}$ phase. Upon subsequent annealing for different times and temperatures, partial or full transformation to the $\mathrm{Ni}_{5} \mathrm{Al}_{3}$ phase has been observed. X-ray diffraction (XRD) studies of the as-processed ingots in this investigation did not detect the presence of the $\mathrm{Ni}_{5} \mathrm{Al}_{3}$ phase, while optical metallographic observations did not reveal two different phases at the ingot bottom. Thus, it can be concluded that after solidification and rapid cooling, the nickelrich $\mathrm{NiAl}$ remained in a single-phase, metastable form at room temperature, or that the amount of $\mathrm{Ni}_{5} \mathrm{Al}_{3}$ precipitated was lower than the detection limits of XRD, and/or it was too fine to be resolved by optical microscopy.

In some cases, the as-processed ingot exhibited a dendritic structure, although in most cases, a non-dendritic, coarsegrained structure was obtained. While a quantitative analysis on this aspect of solidification in the reactive infiltration process has not been undertaken in the present study, two possible reasons for this phenomenon can be proposed: (1) different ingots had slightly different average compositions and, thus, had different liquidus-solidus intervals; and (2) the solidification rates were uncontrolled and could have varied radially from the outside to the inside of the ingot and along the length from the top to the bottom of the ingot. Because the transition from dendritic to equiaxed structure is expected to be sensitive to both the solidification rate and temperature interval of solidification, a change in solidification mechanism from dendritic to equiaxed may be observed in the same ingot at different regions or among different ingots.

While the NiAl-W pseudobinary eutectic phase diagram $^{[29]}$ predicts that significant quantities of tungsten $(2.0$ at. pct W) can be dissolved by molten $\mathrm{NiAl}$ at $1638{ }^{\circ} \mathrm{C}$, little tungsten precipitation was observed (Figure 3), indicating that the contact time with liquid NiAl was short. Exposure to high temperatures can induce homogeneous recrystallization across the cross section of the tungsten fiber. But only peripheral regions of the tungsten fibers had recrystallized (Figures 4(b) and (d)), similar to fiber recrystallization induced by nickel diffusion reported in tungsten fiber reinforced superalloys, ${ }^{[30]}$ and, thus, strongly suggested nickelor aluminum-diffusion-induced recrystallization occurring at the high processing temperatures $\left(1638^{\circ} \mathrm{C}\right)$. This hypothesis is further strengthened by electron microprobe analysis of the NiAl-W interface (Figure 5), showing a nickel concentration profile within the first $20 \mu \mathrm{m}$ of the tungsten fiber with a maximum concentration of 3.5 at. pct close to the matrix interface. Comparison of the untested and creeptested microstructures of tungsten fibers (from the NiAl$\mathrm{W}$ composites) indicated little difference in the size of the

Table III. Summary of Results on the Observation of $\mathrm{Ni}_{5} \mathrm{Al}_{3}$ Reported in Literature

\begin{tabular}{|c|c|c|c|c|c|c|c|c|}
\hline Reference & Year & Authors & $\begin{array}{l}\text { Composition } \\
(\mathrm{Ni}, \text { at. } \mathrm{Pct})\end{array}$ & Processing & Homogenization & $\begin{array}{c}\text { Annealing or } \\
\text { Thermal Cycling }\end{array}$ & $\begin{array}{l}\quad \mathrm{Ni}_{5} \mathrm{Al}_{3} \\
\text { Formation }\end{array}$ & $\begin{array}{c}\text { Observed } \\
\text { by }\end{array}$ \\
\hline 22 & 1993 & Khadkikar et al. & 63.0 & $\begin{array}{l}\text { hot extrusion of } \\
\text { powder blends }\end{array}$ & $4 \mathrm{~h}$ at $1250{ }^{\circ} \mathrm{C}$ & $\begin{array}{l}\text { none } \\
12 \mathrm{~h} \text { at } 550{ }^{\circ} \mathrm{C} \\
30 \text { days at } 550{ }^{\circ} \mathrm{C}\end{array}$ & $\begin{array}{l}\text { none } \\
\text { partial } \\
\text { full }\end{array}$ & $\mathrm{TEM}+\mathrm{XRD}$ \\
\hline 23 & 1994 & Yang and Wayman & $\begin{array}{l}63.0 \\
63.0 \\
63.0 \\
63.0 \\
65.0 \\
65.0 \\
65.0 \\
65.0\end{array}$ & arc melting & $5 \mathrm{~h}$ at $1050^{\circ} \mathrm{C}$ & $\begin{array}{l}\text { none } \\
24 \mathrm{~h} \text { at } 400{ }^{\circ} \mathrm{C} \\
25 \text { days at } 400{ }^{\circ} \mathrm{C} \\
365 \text { days at } 400{ }^{\circ} \mathrm{C} \\
\text { none } \\
24 \text { h at } 400{ }^{\circ} \mathrm{C} \\
25 \text { days at } 400{ }^{\circ} \mathrm{C} \\
365 \text { days at } 400{ }^{\circ} \mathrm{C}\end{array}$ & $\begin{array}{l}\text { none } \\
\text { none } \\
\text { none } \\
\text { partial } \\
\text { none } \\
\text { yes } \\
\text { yes } \\
\text { yes }\end{array}$ & TEM + SAED \\
\hline 24 & 1995 & Schryvers et al. & 62.5 & arc melting & $2 \mathrm{~h}$ at $1250^{\circ} \mathrm{C}$ & $\begin{array}{l}10 \mathrm{~min} \text { at } 550{ }^{\circ} \mathrm{C} \\
2 \mathrm{~h} \text { at } 550{ }^{\circ} \mathrm{C} \\
7 \text { days at } 550{ }^{\circ} \mathrm{C}\end{array}$ & $\begin{array}{l}\text { partial } \\
\text { partial } \\
\text { full }\end{array}$ & TEM \\
\hline 25 & 1996 & Cheng & 65.4 & melt spinning & - & $25^{\circ} \mathrm{C}$ to $650{ }^{\circ} \mathrm{C}$ & partial & XRD + SAED \\
\hline 26 & 1997 & Potapov et al. & 63.8 & $\begin{array}{l}\text { reduction of } \mathrm{Al}_{2} \mathrm{O}_{3} \\
\text { and } \mathrm{NiO}\end{array}$ & $5 \mathrm{~h}$ at $1200^{\circ} \mathrm{C}$ & $\begin{array}{l}5.5 \mathrm{~h} \text { at } 230{ }^{\circ} \mathrm{C} \\
20 \mathrm{~min} \text { at } 300^{\circ} \mathrm{C}\end{array}$ & $\begin{array}{l}\text { yes } \\
\text { yes }\end{array}$ & XRD \\
\hline 27 & 1997 & Lasek et al. & $\begin{array}{l}62.0 \\
62.7 \\
63.4 \\
64.1 \\
64.8 \\
66.2\end{array}$ & $\begin{array}{l}\text { induction melting } \\
\text { of } \mathrm{Ni} \text { and } \mathrm{Al}\end{array}$ & $3 \mathrm{~h}$ at $1250^{\circ} \mathrm{C}$ & $-180{ }^{\circ} \mathrm{C}$ to $900{ }^{\circ} \mathrm{C}$ & $\begin{array}{c}\text { no } \\
\text { no } \\
\text { yes } \\
\text { yes } \\
\text { yes } \\
\text { yes }\end{array}$ & resistometry \\
\hline 28 & 1998 & Ootoshi et al. & $\begin{array}{l}\mathrm{Ni}_{3} \mathrm{Al} / \mathrm{NiAl} \\
\text { (diffusion } \\
\text { couple) }\end{array}$ & $\begin{array}{l}\text { arc melting of } \mathrm{Ni} \\
\text { and } \mathrm{Al}\end{array}$ & 7 days at $1200{ }^{\circ} \mathrm{C}$ & $\begin{array}{l}65 \text { days at } 600^{\circ} \mathrm{C} \\
79 \text { days at } 600^{\circ} \mathrm{C} \\
49 \text { days at } 650^{\circ} \mathrm{C} \\
65 \text { days at } 650^{\circ} \mathrm{C}\end{array}$ & $\begin{array}{l}\text { at interface } \\
\text { at interface } \\
\text { at interface } \\
\text { at interface }\end{array}$ & $\mathrm{TEM}+\mathrm{SAD}$ \\
\hline
\end{tabular}

TEM: transmission electron microscopy; SAED: Selected area electron diffraction; and XRD: X-ray diffraction. 


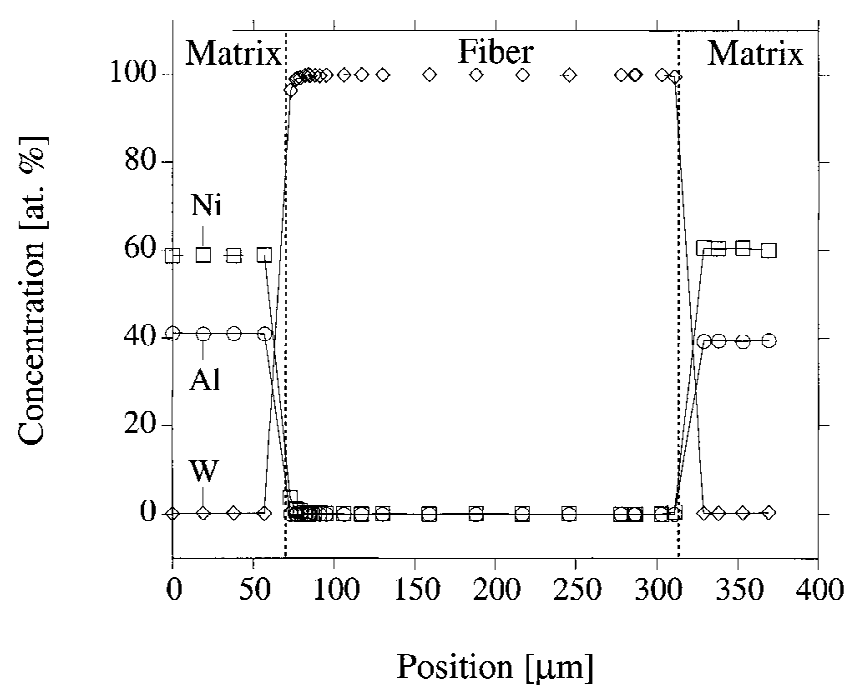

(a)

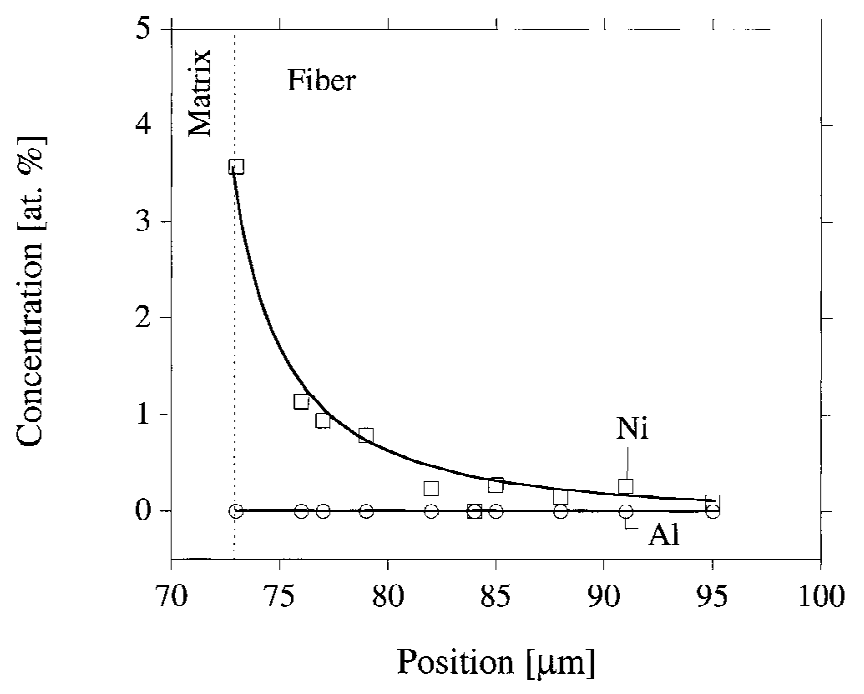

(b)

Fig. 5-Concentration profiles in matrix and fiber (a) across the full diameter of a tungsten fiber and $(b)$ near the NiAl-W interface.

recrystallized zone, indicating little diffusion of nickel into tungsten at test temperatures $\left(715{ }^{\circ} \mathrm{C}\right.$ and $\left.1025{ }^{\circ} \mathrm{C}\right)$. It is also noted that, as recrystallization embrittles tungsten, ${ }^{[31]}$ the partially recrystallized tungsten fibers in the NiAl-W composite are expected to contribute less toward enhancing the low-temperature toughness of the NiAl-W composite.

\section{B. Creep Properties}

\section{Creep of NiAl}

It is well established ${ }^{[2]}$ that creep of $\mathrm{NiAl}$ is governed by dislocation mechanisms for the temperatures, stresses, and grain sizes investigated here. A summary of the stress exponents and activation energies reported in the literature have been reviewed by Noebe et al. ${ }^{[2]}$. Values of stress exponents of $\mathrm{NiAl}$ for a wide variety of grain sizes, including single crystals, cluster within five and seven, for temperatures between $827{ }^{\circ} \mathrm{C}$ and $1127{ }^{\circ} \mathrm{C}$, as expected for dislocation climb-controlled creep. The stress exponents of 5.5 and 5.6

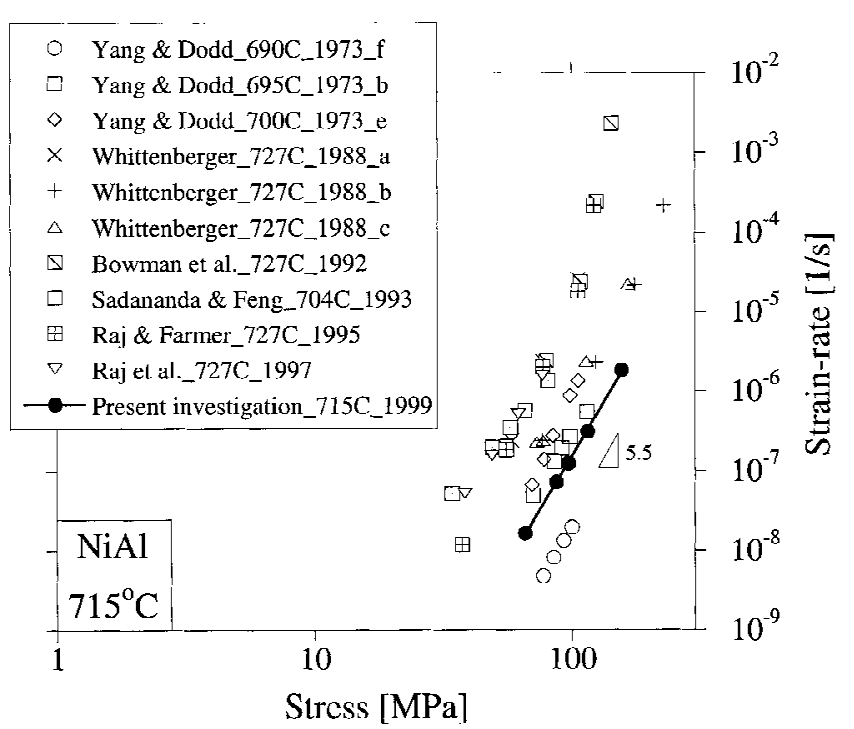

(a)

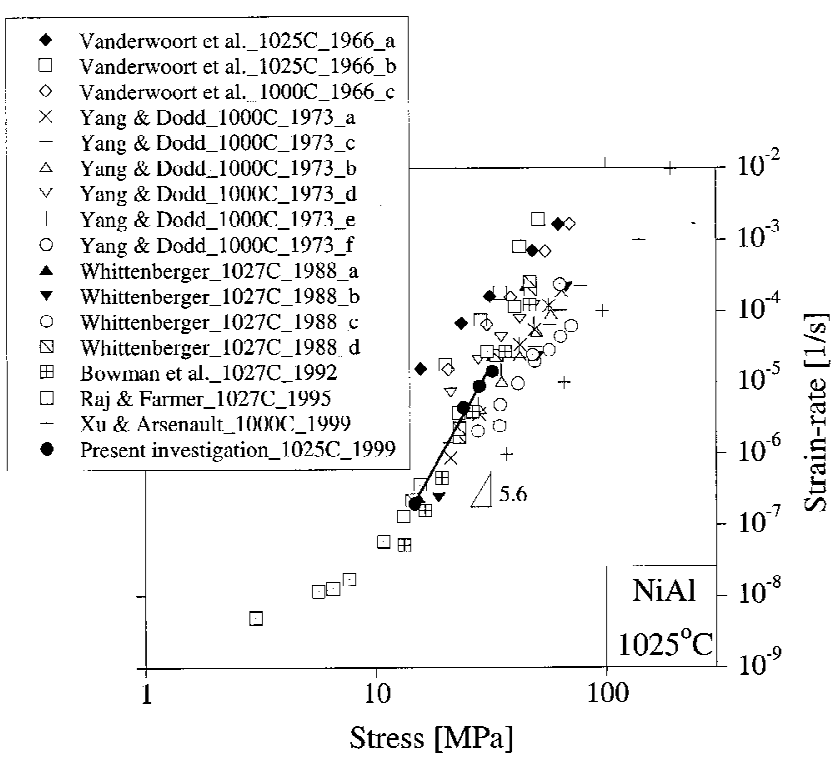

(b)

Fig. 6-Minimum creep rates at (a) $715{ }^{\circ} \mathrm{C}$ and (b) $1025{ }^{\circ} \mathrm{C}$ of $\mathrm{NiAl}$ produced by reactive infiltration (present investigation) compared to prior results on NiAl (Table IV).

(Table II) obtained in this investigation are, thus, quite consistent with established theory on creep of $\mathrm{NiAl}$, while the activation energy of $375 \mathrm{~kJ} / \mathrm{mol}$ obtained in this investigation is higher than that reported for polycrystalline $\mathrm{NiAl}$ ( 283 to $350 \mathrm{~kJ} / \mathrm{mol}$ ) but lower than that reported for single-crystal $\mathrm{NiAl}(440 \mathrm{~kJ} / \mathrm{mol})$. As the activation energy computed here is obtained by considering two temperatures, only a rough approximation of the true activation energy of the system is expected. A review of relevant literature ${ }^{[32-39]}$ summarized in Table IV, indictates that there is a fairly wide scatter band for the observed minimum strain rates at different applied stresses depending on the material composition, level of impurities, grain size, or postprocessing heat treatment. The minimum strain rates observed in this investigation for coarse-grained $\mathrm{NiAl}$ (with a grain size of approximately 200 $\mu \mathrm{m})$ at $1025^{\circ} \mathrm{C}$ and $715^{\circ} \mathrm{C}$ are, thus, quite consistent with literature values (Figure 6). 


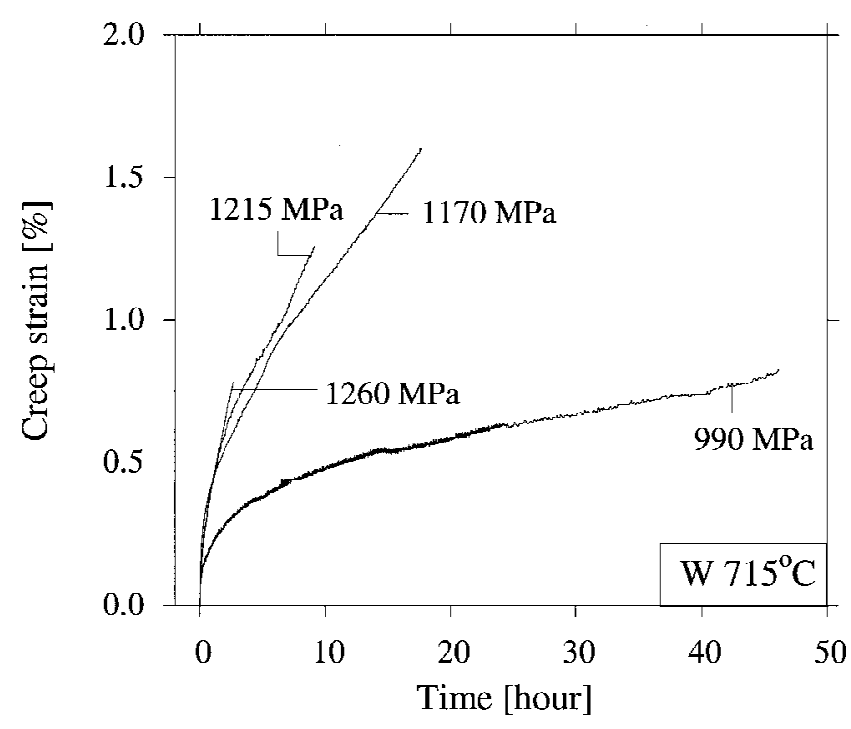

Fig. 7-Tension creep curves of unrecrystallized tungsten wires at $715{ }^{\circ} \mathrm{C}$ at different stresses.

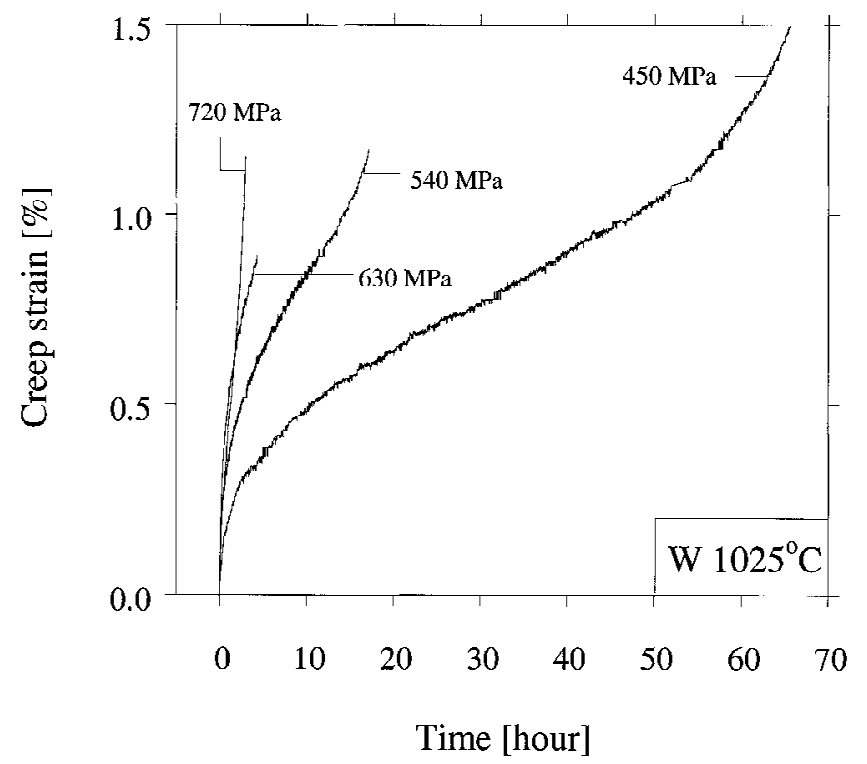

Fig. 8-Tension creep curves of unrecrystallized tungsten wires at 1025 ${ }^{\circ} \mathrm{C}$ at different stresses.

\section{Creep of tungsten}

The sharp variation of stress exponents from 13.6 at 715 ${ }^{\circ} \mathrm{C}$ to 6.7 at $1025{ }^{\circ} \mathrm{C}$ (Figure 9) is most likely indicative of a change in the deformation mechanism from obstaclecontrolled dislocation glide to low-temperature dislocation climb, as predicted by the deformation mechanism map of Frost and Ashby ${ }^{[40]}$ for these temperature and stress ranges.

The measured minimum creep rates of unrecrystallized tungsten wires are many orders of magnitude lower than those reported for recrystallized tungsten ${ }^{[4]}$ (Figure 13). This is most likely due to the fact that the wire drawing process induces a textured microstructure with narrow elongated grains with a very high density of dislocations and dislocation tangles that severely impede dislocation motion. The actual extent of strengthening that can be induced by the wire-drawing process was investigated by Harris and

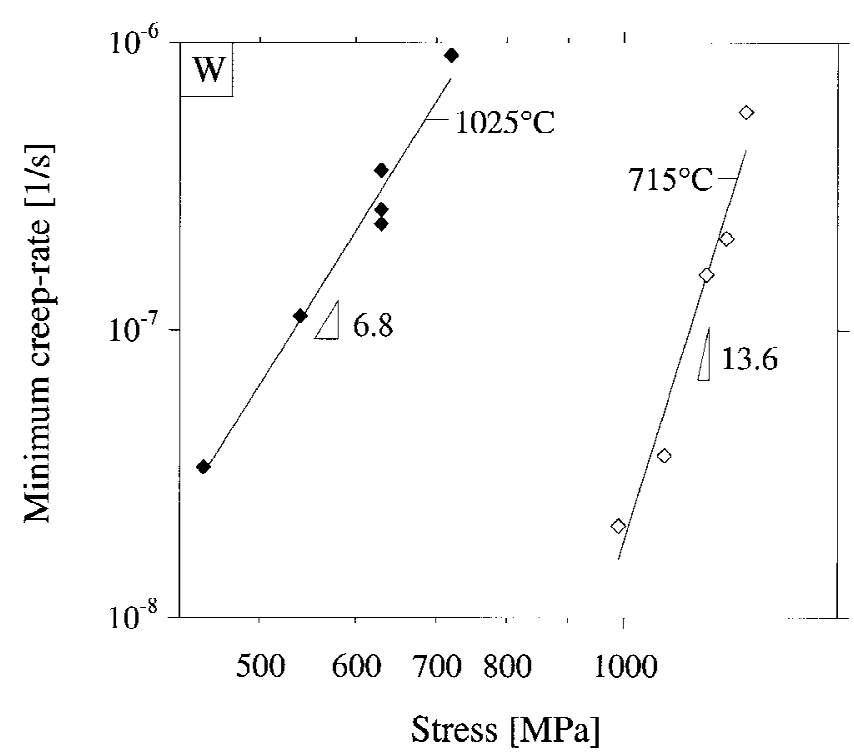

Fig. 9-Experimentally obtained minimum creep rates of unrecrystallized tungsten wires at $715^{\circ} \mathrm{C}$ and $1025^{\circ} \mathrm{C}$.

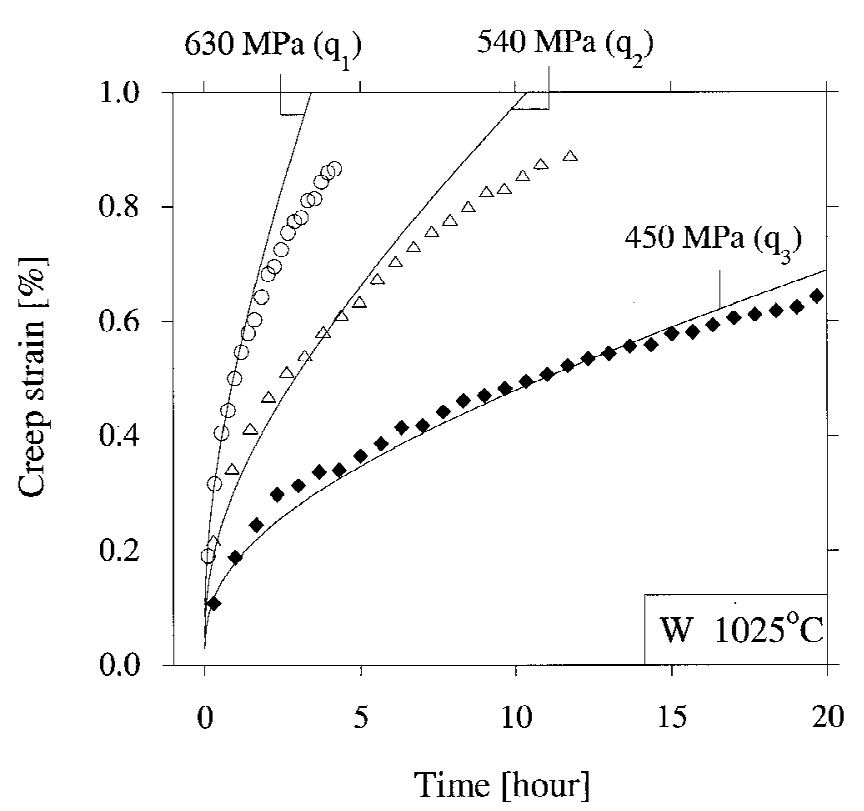

Fig. 10-Primary creep curves of unrecrystallized tungsten wires at 1025 ${ }^{\circ} \mathrm{C}$ modeled using Andrade time law, Eq. [2] where $q_{1}=2.7 \cdot 10^{-4} \mathrm{~s}^{-1 /}$ ${ }^{3}, q_{2}=1.8 \cdot 10^{-4} \mathrm{~s}^{-1 / 3}$, and $q_{3}=1.1 \cdot 10^{-4} \mathrm{~s}^{-1 / 3}$ (symbols represent experimental data).

Ellison $^{[42]}$ using 76- $\mu \mathrm{m}$-diameter drawn and unrecrystallized tungsten wires (Figure 13). The minimum creep rates of unrecrystallized tungsten wires with diameter of $250 \mu \mathrm{m}$ obtained in this investigation correlate reasonably well with the minimum creep rates obtained by Harris and Ellison.

\section{Creep of NiAl-W composites}

Unidirectionally reinforced long-fiber composite systems loaded longitudinally in the direction of fibers, in general, exhibit three-stage creep behavior with primary, secondary, and tertiary creep regimes. The primary and tertiary creep behavior are discussed in References 43 and 44, respectively. In this article, we discuss the secondary creep stage that is 


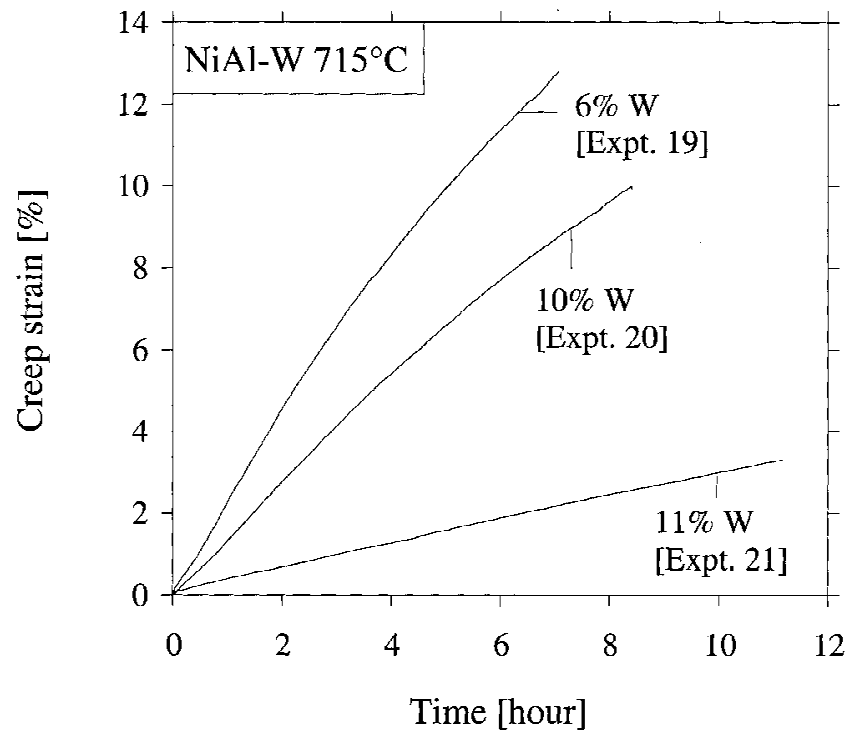

Fig. $11-$ Creep curves at $715{ }^{\circ} \mathrm{C}$ of NiAl-W composites with different volume fractions of tungsten, at an applied composite stress of $300 \mathrm{MPa}$.

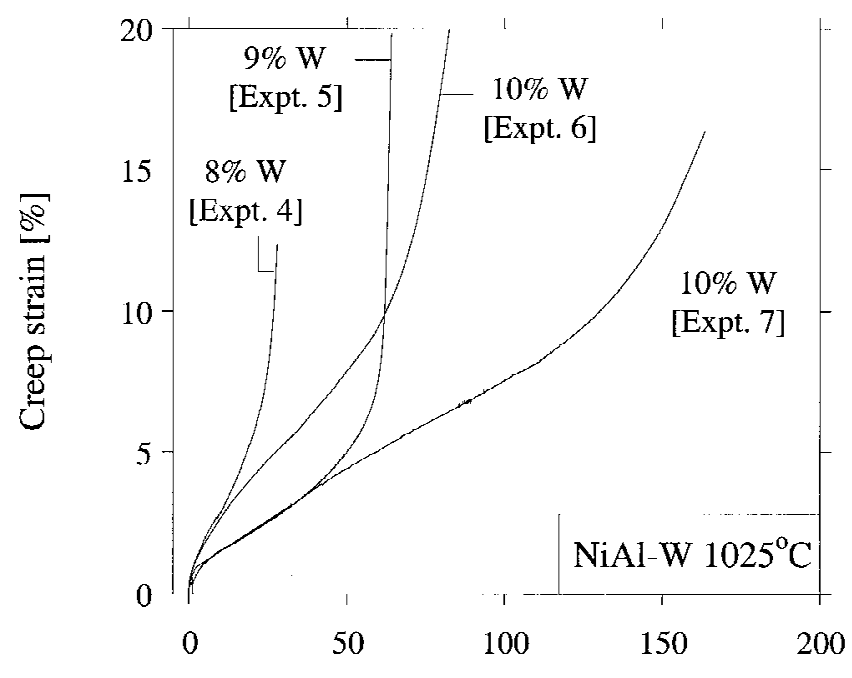

Time [hour]

Fig. 12-Creep curves at $80 \mathrm{MPa}$ and $1025{ }^{\circ} \mathrm{C}$ of NiAl-W composites exhibiting primary, secondary, and tertiary behavior.

established when both creeping constituents (i.e., matrix and fiber) attain their respective secondary stages. The composite secondary creep behavior has been modeled by McLean ${ }^{[45]}$ using a rule-of-mixtures formulation, where the composite creep stress $\sigma_{\text {comp }}$ is related to the fiber stress $\sigma_{f}$, the matrix stress $\sigma_{m}$, and the fiber volume fraction $v_{f}$ as

$$
\sigma_{\text {comp }}=v_{f} \sigma_{f}+\left[1-v_{f}\right] \sigma_{m}
$$

Using Eq. [1] the minimum strain rate of the composite $\dot{\varepsilon}_{\text {comp }}$ is then obtained as an implicit function of the applied composite stress: ${ }^{[45]}$

$$
\sigma_{\text {comp }}=v_{f}\left[\frac{\varepsilon_{\text {comp }}}{K_{f}}\right]^{1 / n_{f}}+\left[1-v_{f}\right]\left[\frac{\dot{\varepsilon}_{\text {comp }}}{K_{m}}\right]^{1 / n_{m}}
$$

where $n$ represents stress exponent with subscripts $m$ and $f$

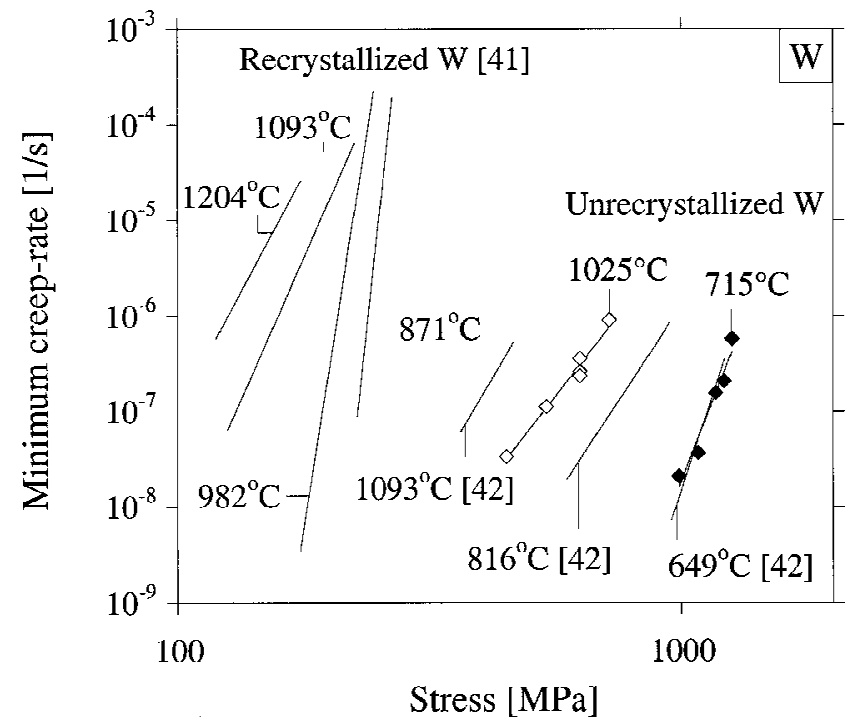

Fig. 13-Minimum creep rates of tungsten wires at $715^{\circ} \mathrm{C}$ and $1025^{\circ} \mathrm{C}$ (present investigation) compared to those of recrystallized tungsten ${ }^{[41]}$ and as-drawn tungsten wires $(76-\mu \mathrm{m}$ diameter $) .{ }^{[42]}$

denoting matrix and fiber, respectively. It has been demonstrated $^{[46]}$ that the zone of dislocation interaction with the fibers is on the order of about $1 \mu \mathrm{m}$. Hence, in composites with large fiber diameters $(>100 \mu \mathrm{m})$, the effects of dislocation interaction at the fiber-matrix-interface are expected to be small and are ignored in this model analysis.

As shown in Figures 14 and 15, the observed compressive minimum creep rates of the $\mathrm{NiAl}-\mathrm{W}$ composites correlate reasonably well with model predictions (Eq. [4]) at $715{ }^{\circ} \mathrm{C}$ and $1025^{\circ} \mathrm{C}$ for most experiments. Deviations from the model predictions by more than a factor of 2 were, however, observed in some experiments. These could be due to a number of factors that influence the creep behavior of $\mathrm{NiAl}$ and tungsten, as the following qualitatively discusses. The observed creep rate of the NiAl-W composites could be higher than predicted by the model if (1) there are significant deviations in the $\mathrm{NiAl}$ matrix composition from the equiatomic stoichiometric composition; and (2) the creep strength of the tungsten fibers is reduced due to partial recrystallization (Figure 4(b) through (d)). On the other hand, the creep rate of the composite could be lower than predicted if (1) the creep strength of the $\mathrm{NiAl}$ matrix is enhanced by tungsten which dissolved during contact with the liquid matrix and which subsequently formed an interdendritic eutectic phase at the NiAl grain boundaries upon solidification (Figure 3); and (2) the tungsten fibers are solid-solution strengthened by diffusion of nickel into the fibers during processing. Thus, depending on the degree of dominance of each of the above factors, an overall strengthening or weakening of the NiAl-W composite could be obtained, explaining the scatter between observed and predicted creep rates in Figures 14 and 15.

\section{CONCLUSIONS}

Reactive infiltration processing was investigated for bulk and reinforced $\mathrm{NiAl}$.

1. Reactive infiltration of nickel-wire preforms with low surface-area-to-volume ratio, high permeability, and regular infiltration paths produces homogeneous, pore-free 
Table IV. Summary of Creep Results of NiAl at/near $715^{\circ} \mathrm{C}$ and $1025{ }^{\circ} \mathrm{C}$ Reported in the Literature

\begin{tabular}{|c|c|c|c|c|c|c|c|c|c|c|}
\hline Reference & Year & Authors & $\begin{array}{c}\text { Processing } \\
\text { Technique }\end{array}$ & At. Pct Ni & Impurities & $\begin{array}{l}\text { Grain size } \\
(\mu \mathrm{m})\end{array}$ & $\begin{array}{l}\text { Postprocessing } \\
\text { Heat Treatment } \\
\end{array}$ & Test* & $\begin{array}{c}\text { Temperature } \\
\left({ }^{\circ} \mathrm{C}\right) \\
\end{array}$ & Atmosphere \\
\hline \multirow[t]{3}{*}{32} & \multirow{3}{*}{$\begin{array}{l}1966 \mathrm{a} \\
1966 \mathrm{~b} \\
1966 \mathrm{c}\end{array}$} & Vanderwoort et al. & \multirow{3}{*}{$\begin{array}{l}\text { induction melting } \\
\text { of } \mathrm{Al}, \mathrm{Ni}+ \\
\text { chill casting }\end{array}$} & 46.00 & $\mathrm{Fe}, \mathrm{Cu}, \mathrm{Mg}$ & 577 & none & $\mathrm{C}$ & 1025 & vacuum \\
\hline & & & & 49.60 & $\mathrm{Fe}, \mathrm{Cu}, \mathrm{Mg}$ & 1000 & none & $\mathrm{C}$ & 1025 & vacuum \\
\hline & & & & 56.00 & $\mathrm{Fe}, \mathrm{Cu}, \mathrm{Mg}$ & 577 & none & $\mathrm{C}$ & 1025 & vacuum \\
\hline \multirow[t]{6}{*}{33} & \multicolumn{2}{|c|}{ 1973a Yang and Dodd } & \multirow[t]{6}{*}{ chill casting } & 50.00 & N/A & 450 & at $1300 \mathrm{~K}$ & CL-C & 1000 & argon \\
\hline & $1973 b$ & & & 49.00 & N/A & 200 to 250 & at $1300 \mathrm{~K}$ & CL-C & 695 and 1000 & argon \\
\hline & $1973 c$ & & & 48.00 & N/A & 200 to 250 & at $1300 \mathrm{~K}$ & CL-C & 1000 & argon \\
\hline & $1973 d$ & & & 46.00 & N/A & 200 to 250 & at $1300 \mathrm{~K}$ & CL-C & 1000 & argon \\
\hline & $1973 \mathrm{e}$ & & & 51.00 & N/A & 200 to 250 & at $1300 \mathrm{~K}$ & $\mathrm{CL}-\mathrm{C}$ & 700 and 1000 & argon \\
\hline & $1973 \mathrm{f}$ & & & 55.00 & N/A & 200 to 250 & at $1300 \mathrm{~K}$ & CL-C & 690 and 1000 & argon \\
\hline \multirow[t]{4}{*}{34} & \multicolumn{2}{|c|}{ 1988a Whittenberger } & \multirow{4}{*}{$\begin{array}{l}\text { hot extrusion of } \\
\text { gas-atomized } \\
\text { prealloyed } \\
\text { powders }\end{array}$} & 50.80 & N/A & 17 & none & $\mathrm{CV}-\mathrm{C}$ & 727 and 1027 & air \\
\hline & $1988 b$ & 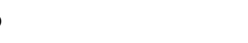 & & 51.75 & N/A & 5 & none & $\mathrm{CV}-\mathrm{C}$ & 727 and 1027 & air \\
\hline & $1988 \mathrm{c}$ & & & 51.75 & N/A & 9 & $16 \mathrm{~h}$ at $1390 \mathrm{~K}$ & CV-C & 727 and 1027 & air \\
\hline & $1988 d$ & & & 51.75 & N/A & 18 & none & $\mathrm{CV}-\mathrm{C}$ & 1027 & air \\
\hline 35 & 1992 & Bowman et al. & $\begin{array}{l}\text { hot extrusion of } \\
\text { vacuum-atom- } \\
\text { ized prealloyed } \\
\text { powders }\end{array}$ & 49.40 & $\mathrm{C}, \mathrm{O}, \mathrm{S}$ & 12 to 22 & none & $\mathrm{DC}-\mathrm{T} / \mathrm{C}$ & 727 and 1027 & air \\
\hline 36 & 1993 & Sadananda and Feng & $\begin{array}{l}\text { rapid solidifica- } \\
\text { tion }+ \text { hot } \\
\text { extrusion }\end{array}$ & 47.75 & $\mathrm{Zr}, \mathrm{C}$ & 20 & none & CL-T & 704 & air \\
\hline 37 & 1995 & Raj and Farmer & $\begin{array}{l}\text { hot extrusion of } \\
\text { vacuum-atom- } \\
\text { ized prealloyed } \\
\text { powders }\end{array}$ & 49.40 & $\mathrm{C}, \mathrm{O}$ & 23 & none & CL-C & 727 and 1027 & air \\
\hline 38 & 1997 & Raj et al. & $\begin{array}{l}\text { induction melting } \\
\quad+\text { hot } \\
\quad \text { extrusion }\end{array}$ & 49.60 & $\mathrm{C}, \mathrm{N}, \mathrm{O}$ & 35 & none & CL-C & 727 & air? \\
\hline 39 & 1999 & $\mathrm{Xu}$ and Arsenault & $\begin{array}{l}\text { hot vacuum } \\
\text { pressing }\end{array}$ & 50.00 & N/A & 5 & $4 \mathrm{~h}$ at $1623 \mathrm{~K}$ & $\mathrm{CD}-\mathrm{C}$ & 1000 & vacuum \\
\hline
\end{tabular}

$* \mathrm{CL}=$ constant load, $\mathrm{CV}=$ constant velocity, $\mathrm{DC}=$ displacement controlled, $\mathrm{C}=$ compression, $\mathrm{T}=$ tension, and $\mathrm{CD}=$ constant displacement.

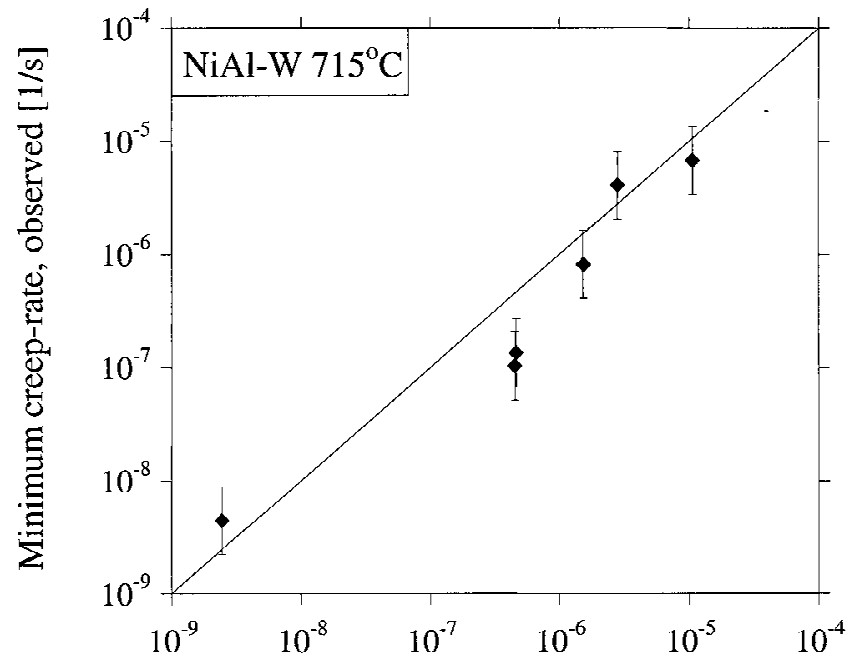

Minimum creep-rate, predicted [1/s]

Fig. 14-Comparison of the minimum creep rates predicted by Eq. [4] with experiments for NiAl-W composites at $715^{\circ} \mathrm{C}$.

$\mathrm{NiAl}$ microstructures with some macroscopic composition gradients.

2. Homogeneous, pore-free NiAl reinforced with continuous, unidirectional tungsten fibers was fabricated by reactive infiltration. Limited dissolution and recrystallization

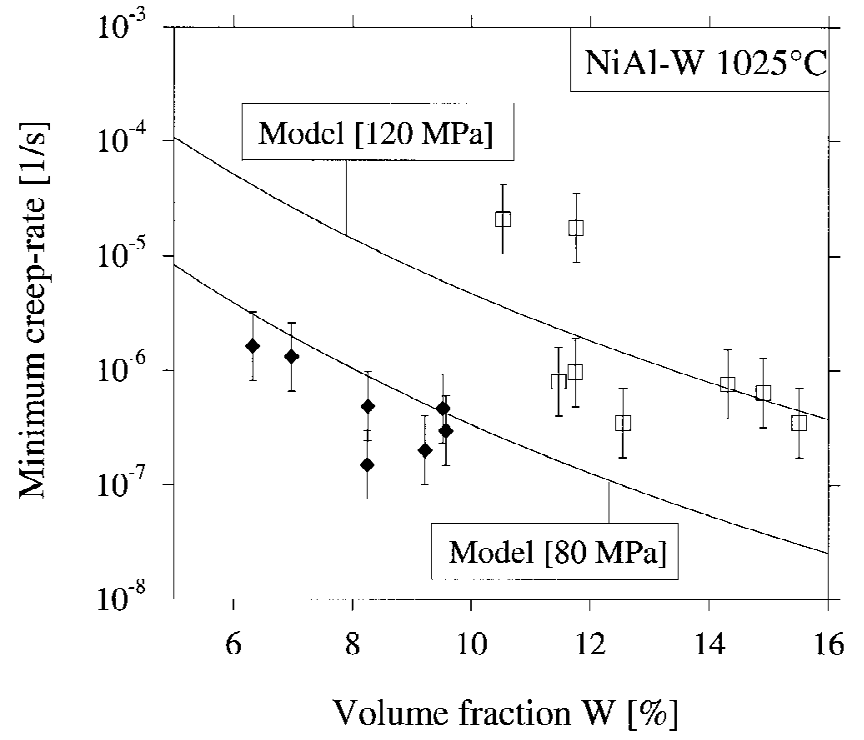

Fig. 15-Comparison of the minimum creep rates predicted by Eq. [4] with experiments for NiAl-W composites at $1025{ }^{\circ} \mathrm{C}$ for $80 \mathrm{MPa}(\downarrow)$ and $120 \mathrm{MPa}(\square)$.

of tungsten were observed because of the low solubility of tungsten in $\mathrm{NiAl}$ and the short time at high processing temperature, respectively. 
The compressive creep behavior of reactively processed $\mathrm{NiAl}$ and tungsten fiber-reinforced $\mathrm{NiAl}$ composites and tensile creep behavior of tungsten fibers were investigated at $715^{\circ} \mathrm{C}$ and $1025^{\circ} \mathrm{C}$.

1. The observed creep behavior of reactively processed $\mathrm{NiAl}$ correlated well with that of conventionally processed NiAl.

2. The secondary creep behavior of as-drawn unrecrystallized tungsten fibers is in reasonable agreement with literature results.

3. The secondary creep of NiAl-W composites was characterized by a stable steady-state behavior. Using the measured secondary-stage creep properties of unreinforced $\mathrm{NiAl}$ and tungsten fibers, the observed composite minimum strain rates correlated well with the rule-of-mixtures isostrain model considering both creeping phases.

\section{ACKNOWLEDGMENTS}

This work was supported by the National Science Foundation through Grant No. MSS 9201843, monitored by Dr. B. McDonald. TAV and DCD acknowledge the financial support of the Department of Materials Science and Engineering, MIT, in the form of teaching assistantships and the AMAX career development chair, respectively. The authors also thank Professor A. Mortensen and Dr. C. San Marchi for many helpful discussions and Professor R. Ballinger and Messrs. D. Grundy and P. Stahl for assistance with creep testing of tungsten fibers. TAV acknowledges Professor S. Suresh for funding in the form of a postdoctoral position at MIT during which time the preparation of this manuscript was completed.

\section{REFERENCES}

1. D.B. Miracle: Acta Metall. Mater, 1993, vol. 41, pp. 649-84.

2. R.D. Noebe, R.R. Bowman, and M.V. Nathal: Int. Mater. Rev., 1993, vol. 38, pp. 193-232.

3. D.M. Dimiduk, D.B. Miracle, and C.H. Ward: Mater. Sci. Technol., 1992, vol. 8, pp. 367-75.

4. R. Darolia and W.S. Walston: Structural Intermetallics 1997, M.V. Nathal, R. Wagner, R. Darolia, M. Yamaguchi, C.T. Liu, P.L. Martin, and D.B. Miracle, eds., TMS, Warrandale, PA, 1996, pp. 585-94.

5. N.S. Stoloff: Metall. Trans. A, 1993, vol. 24A, pp. 561-67.

6. R.D. Noebe, F.J. Ritzert, A. Misra, and R. Gibala: Iron Steel Inst. Jpn., 1991, vol. 31, pp. 1172-1200.

7. A. Misra, Z.L. Wu, M.T. Kush, and R. Gibala: Phil. Mag., 1998, vol. 78, pp. 533-50.

8. S. Nourbakhsh, F.L. Liang, and H. Margolin: Adv. Mater. Proc., 1988, vol. 3, pp. 57-78.

9. D.E. Alman and N.S. Stoloff: Int. J. Powder Metall., 1991, vol. 27, pp. 29-41.

10. Z.H. Munir and U. Anselmi-Tamburini: Mater. Sci. Rep., 1989, vol. 3, pp. 277-365.
11. H. Chen, M. Kaya, and R.W. Smith: Mater. Lett., 1992, vol. 13, pp. $180-83$.

12. K. Suganuma: Mater. Lett., 1993, vol. 16, pp. 22-25.

13. D.C. Dunand, J.L. Sommer, and A. Mortensen: Metall. Trans. A, 1993, vol. 24A, pp. 2161-70.

14. D.C. Dunand: Mater. Manuf. Proc., 1995, vol. 10, pp. 373-403.

15. C.W. SanMarchi and A. Mortensen: Metall. Mater. Trans. A, 1998, vol. 29A, pp. 2819-28.

16. A.K. Misra: Report No. 4171, NASA, Washington, DC, 1988.

17. C.W. SanMarchi: Ph.D. Thesis, Massachusetts Institute of Technology, Cambridge, MA, 1997.

18. T.A. Venkatesh: Ph.D. Thesis, Massachusetts Institute of Technology, Cambridge, MA, 1998.

19. J.A. Isaacs, F. Taricco, V.J. Michaud, and A. Mortensen: Metall. Trans. A, 1991, vol. 22A, pp. 2855-62.

20. T.A. Venkatesh, C.W. SanMarchi, A. Mortensen, and D.C. Dunand: in High Temperature Ordered Intermetallic Alloys, C.C. Koch, ed., Materials Research Society, Pittsburgh, PA, 1997, pp. 737-42.

21. P. Nash, M.F. Singleton, and J.L. Murray: Phase Diagrams of Binary Nickel Alloys, P. Nash, ed., ASM, Materials Park, OH, 1991, pp. 3-11.

22. P.S. Khadkikar, I.E. Locci, K. Vedula, and G.M. Michal: Metall. Trans. A, 1993, vol. 24A, pp. 83-94.

23. J.H. Yang and C.M. Wayman: Intermetallics, 1994, vol. 2, pp. 111-19.

24. D. Schryvers, Y. Ma, L. Toth, and L. Tanner: Acta Mater., 1995, vol. 43, pp. 4045-56.

25. T. Cheng: J. Mater. Sci. Lett., 1996, vol. 15, pp. 285-89.

26. P.L. Potapov, S.Y. Song, V.A. Udovenko, and S.D. Prokoshkin:Metall. Mater. Trans. A, 1997, vol. 28A, pp. 1133-42.

27. J. Lasek, T. Chraska, P. Krecek, and P. Bartuska: Scripta Mater, 1997, vol. 37, pp. 897-902.

28. Y. Ootoshi, K. Fujiwara, Z. Horita, and M. Nemoto: Mater. Trans. JIM, 1998, vol. 39, pp. 225-29.

29. Z.M. Alkaseeva: Ternary Alloys -A Comprehensive Compendium of Evaluated Constitutional Data and Phase Diagrams, G. Petzow and G. Effenberg, eds., Weinheim, New York, 1993, pp. 49-57.

30. D.M. Essock: in Composites, T.J. Reinhart, ed., ASM, Metals Park, OH, 1987, pp. 878-88.

31. R. Warren: Sintered Metal-Ceramic Composites, G.S. Upadhyaya, ed., Elsevier, New York, NY, 1983, pp. 215-37.

32. R.R. Vandervoort, A.K. Mukherjee, and J.E. Dorn: Trans. ASM, 1966, vol. 59, pp. 930-44.

33. W.J. Yang and R.A. Dodd: Met. Sci. J., 1973, vol. 7, pp. 41-47.

34. J.D. Whittenberger: J. Mater. Sci., 1988, vol. 23, pp. 235-40.

35. R.R. Bowman, R.D. Noebe, S.V. Raj, and I.E. Locci: Metall. Trans. A, 1992, vol. 23A, pp. 1493-1508.

36. K. Sadananda and C.R. Feng: Mater. Sci. Eng., 1993, vol. A170, pp. 199-214.

37. S.V. Raj and S.C. Farmer: Metall. Mater. Trans. A, 1995, vol. 26A, pp. 343-56.

38. S.V. Raj, A. Garg, and T.R. Bieler: High-Temperature Ordered Intermetallic Alloys VII, C.C. Koch et al., eds., Materials Research Society, Pittsburgh, PA, 1997, pp. 473-78.

39. K. Xu and R.J. Arsenault: Acta Mater, 1999, vol. 47, pp. 3023-40.

40. H.J. Frost and M.F. Ashby: Deformation-Mechanism Maps: The Plasticity and Creep of Metals and Ceramics, Pergamon, New York, NY, 1982, pp. 34-35.

41. J.W. Pugh: Proc. ASTM, 1957, vol. 57, pp. 909-16.

42. B. Harris and E.G. Ellison: Trans. ASM, 1966, vol. 59, pp. 744-54.

43. T.A. Venkatesh and D.C. Dunand: Acta Mater, 1999, vol. 47, pp. 4275-82.

44. T.A. Venkatesh and D.C. Dunand: unpublished research, 1999.

45. M. McLean: Mechanical Behavior of In-Situ Composites, The Metals Society, London, 1983, pp. 207-56.

46. S. Goto and M. McLean: Acta Mater., 1991, vol. 39, pp. 153-64. 